\title{
PENGEMBANGAN LKS BERBASIS PENDEKATAN OPEN-ENDED UNTUK MENINGKATKAN KEMAMPUAN BERPIKIR KREATIF MATEMATIS SISWA
}

\author{
${ }^{1}$ Ratna Juwita, ${ }^{2}$ Arinka Putri Utami, ${ }^{3}$ Palupi Sri Wijayanti \\ ${ }^{1,2,3}$ Universitas PGRI Yogyakarta, Jl. PGRI I No.117 Sonosewu Kasihan Bantul, Fax (0274) 376808 \\ e-mail: ratnaj225@gmail.com
}

\begin{abstract}
Abstrak
Tujuan penelitian ini adalah untuk mengetahui mengembangkan LKS berbasis pendekatan Open-Ended untuk meningkatkan kemampuan berfikir kreatif siswa yang valid, dan mengetahui hasil uji praktikalitas pada pengguna LKS. Penelitian ini menggunakan model pengembangan ADDIE dimodifikasi menjadi ADD yang terdiri dari tiga tahap yakni Analysis, Design, dan Development. Teknik analisis data pada uji valid dan uji praktikalitas menggunakan skala Likert dengan menggunakan lembar validasi, lembar praktilalisasi dan lembar angket. Adapun teknik pengolahan data dilakukan dengan menggunakan rumus valid dan praktis, kemudian memberikan kriteria valid serta praktis mengacu pada kriteria yang telah ditetapkan. Hasil validasi dilakukan oleh 3 orang validator menunjukkan bahwa secara keseluruhan LKS memperoleh rata-rata sebesar $84,7 \%$. Sementara hasil praktikalitas pengguna LKS dari 5 orang siswa kelas VII SMPN 1 Kasihan diperoleh rata-rata kepraktisan LKS sebesar 75\%. Dengan demikian, dapat disimpulkan bahwa pengembangan LKS berbasis pendekatan Open-Ended untuk meningkatkan kemampuan berpikir kreatif siswa yang dikembangkan, berada pada kriteria sangat valid dan sangat praktis.
\end{abstract}

Kata Kunci: pengembangan LKS, Open-Ended, Berpikir Kreatif

\begin{abstract}
The purpose of this research is to find develop LKS based approach open-ended to improve the capacity to think creative students valid and known the result test practicality users on LKS. This research used the model development addie was modified into add consists of three stages the analysis, design, and development. Technique data analysis on test valid and the practicality use likert scale by using validation sheet, practitioner lember and questionnaire. As for technique data processing done with using formulas valid and practicality, then provided criteria valid and practical referring to the criteria which had been set.The results of validation done by 3 people validator show that on the whole LKS have an average of 84,7\%.Temporary outgrowth practical users LKS of the five people who students VII SMPN 1 KASIHAN obtained the average practicality LKS of 75 $\%$.Thus, can be concluded that the development LKS based approach open-ended to improve the capacity to think creative students who developed to a criterion perfectly valid and very practical.
\end{abstract}

Keywords: Development LKS, open-ended, creative thinking

\section{PENDAHULUAN}

Masalah yang menjadi pembicaraan dalam pendidikan di indonesia adalah rendahnya kemampuan berfikir kreatif. Selain rendahnya kemampuan berpikir kreatif ternyata siswa masih kebingungan dalam menyelesaikan masalah kontekstual. Pengembangan media pembelajaran menjadi faktor yang diperlukan untuk meningkatkan kemampuan berpikir kreatif. Maka dari itu, pendidik harus berkerja keras dan berupaya untuk menciptakan generasi yang handal dan kreatif. Menyikapi kenyataan yang terjadi di atas sekaligus merupakan tantangan bagi dunia pendidikan, maka paradigma pendidikan harus di ubah dari 
yang semula "teacher center" menjadi "student center" sesuai dengan yang tetapkan dalam permendikbud tahun 2016.

Kemampuan berpikir kreatif siswa dalam menyelesaiakan soal kontekstual pada mata pelajaran matematika masih menjadi pembicaraan. Karena kata matematika masih menjadi hal yang ditakutkan bagi siswa karena materinya sulit. Padahal kenyataanya, bukan karena materi yang sulit, tetapi kurangnya kemampuan berpikir kreatif siswa dalam pemecahan masalah. Permasalahan yang terjadi dan dihadapi saat ini adalah lemahnya kegiatan pembelajaran karena siswa kurang didorong untuk mengembangkan kemampuan berfikir (J Hamdayana, 2014).

Sesuai juga dengan yang dikemukakan (Anwar, Johar, \& Juandi, 2015) bahwa perlakuan siswa sebagai objek mengakibatkan siswa tidak mendapat kesempatan untuk mengembangkan ide-ide kreatif, berpikir logis dan menemukan alternatif pemecahan masalah. Namun, siswa didorong mempelajari matematika dengan menghafal rumus atau konsep tanpa tahu maknanya dan tidak didorong untuk dapat mencari alternatif lain yang dipakai untuk menyelesaikan suatu persoalan yang mungkin lebih efektif. Selain kondisi pembelajaran matematika tersebut. Siswa juga mengeluh dan mengalami kesulitan dalam mempelajari matematika, siswa tidak tertarik untuk mengikuti pelajaran matematika, dan siswa memperoleh hasil belajar yang rendah pada pelajaran matematika.

Anggapan tersebut dapat diatasi jika dalam proses pembelajaran siswa tidak hanya sebagai objek tetapi berilah kesempatan siswa untuk mengembanngkan ide-ide kreatif atau pikiran kreatifnya dalam memecahkan masalah. Maka dari itu tugas dari seorang pendidiklah yang berpengaruh terhadap bagaimana cara supaya siswa dapat memulai menggunakan kemampuan berpikir kreatifnya dalam menyelesaikan soal.

Salah satu cara untuk menentukan keberhasilan dalam meningkatkan kemampuan kreatif yaitu dengan pengembangan media yang berupa LKS atau sering di sebut juga LKPD. Karena hasil dari lapangan, LKPD yang dibuat masih belum baik. Dimana dalam pengembangan LKPD ini dibutuhkan suatu pendekatan yang cocok untuk meningkatkan kemampuan berpikir kreatif. Maka dari itu, pengembangan media yang berupa LKPD pada penelitian kali ini menggunakan pendekatan open-ended.

Berpikir kreatif yaitu suatu proses yang digunakan ketika seseorang individu mendatangkan atau memunculkan suatu ide baru, dimana ide baru tersebut merupakan gabungan dari ide-ide sebelumnya yang belum pernah diwujudkan. Berpikir kreatif sesungguhnya adalah suatu kemampuan berpikir yang berawal dari adanya kepekaan terhadap situasi yang sedang dihadapi, misalnya dalam situasi itu terdeteksi atau teridentifikasi adanya masalah yang ingin atau harus diselesaikan (Sabandar, 2012). Evans mengemukakan bahwa berpikir kreatif terdeteksi dalam empat bentuk yaitu: kepekaan

Prima, Vol. 3, No. 1, Januari 2019, 35-43. 
(sensitivity), kelancaran (fluency), keluwesan (flexibiliy), dan keaslian (originality) (J.R, 1991).

Dapat disimpulkan bahwa berpikir kreatif merupakan suatu proses kepekaan awal yang muncul terhadap situasi yang didapat dari masalah-masalah untuk memunculkan ide baru dalam penyelesaianya. Dalam meningkatkan kemampuan berpikir kreatif ini, terdapat beberapa bentuk yaitu kepekaan. Kepekaan, kelancaran, keluwesan, dan keaslian. Bentukbentuk tersebut dapat dilakukan ketika siswa mengadalisis suatu masalah atau soal kontektual. Untuk memnuhi semuanya, maka diperlukan suatu media pembelajaran

Media yang digunakan dalam penelitian ini yaitu LKPD atau sering di sebut juga LKS, dimana sebelumnya sudah dijelaskan bahwa pengembangan LKPD di Indonesia masih belum baik. Menurut Diknas Pedoman Umum Pengembangan Bahan Ajar, Lembar Kerja Siswa (LKS) atau lembar kerja peserta didik (LKPD) adalah lembaran-lembaran berisi tugas yang harus dikerjakan oleh siswa (Andi, 2011). Lembaran biasanya berupa petunjuk, langkahlangkah untuk menyelesaikan suatu tugas. LKPD merupakan salah satu perangkat pembelajaran yang digunakan untuk mendukung proses pembelajaran agar lebih optimal dan tidak membosankan. LKPD merupakan salah satu alternatif pembelajaran yang tepat bagi peserta didik karena LKPD membantu peserta didik untuk menambah informasi tentang konsep yang dipelajarinya melalui kegiatan belajar secara sistematis. Isi pesan LKPD harus memperhatikan unsur-unsur penulisan media grafis, hierarki materi (matematika) dan pemilihan pertanyaan-pertanyaan sebagai stimulus yang efisien dan efektif (Rohati, 2014).

Dari penjelasan di atas LKPD yang baik adalah LKPD yang dapat membuat peserta didik untuk menarik perhatian dengan menggunakan media grafis. LKPD yang dikembangkan dengan pendekatan open-ended merupakan alternative LKPD yang dapat meningkatkan kemampuan berpikir kreatif dan pembelajaran lebih baik. Pendekatan openended dapat membangun kemampuan siswa berpikir kritis dan kreatif untuk memunculkan pemahaman konsep-konsep, ide-ide, gagasan dan pola serta mengembangkan kreativitas siswa.

Pendekatan open-ended merupakan pendekatan pembelajaran yang terbuka, memiliki banyak solusi untuk memecahkan masalah, seperti yang dikemukakan oleh Shimada bahwa pembelajaran dengan pendekatan open-ended menyajikan suatu permasalahan yang memiliki beragam penyelesaian/ metode penyelesaian (S, 1997). Pendekatan open-ended mampu meningkatkan kemampuan berpikir kritis dan kreatif siswa. Karakteristik dari pembelajaran dengan pendekatan open-ended adalah memberikan masalah terbuka pada awal pembelajaran 
(terutama yang bersifat kontekstual) yang mempunyai beberapa jawaban (Soeyono, 2014). Pendekatan ini dapat mengasah kemampuan berpikir kreatif peserta didik. Selain mengasah kemampuan, pendekatan ini memberikan solusi, cara/ metode dalam memecahkan masalah tidak hanya dengan satu cara saja. Banyaknya cara untuk memecahkan masalah dapat membuat ragu akan jawaban dari masalah tersebut. Maka dari itu, dalam pendekatan openended bukan mentitikberatkan pada jawaban yang banyak, tetapi pada proses penyelesaian masalah dengan banyak cara atau pencarian untuk memecahkan masalah lebih dari satu cara.

Berdasarkan uraian di atas, maka peneliti menyimpulkan rumusan masalah dalam penelitian ini adalah:

1. Bagaimana produk pengembangan LKPD berbasis pendekatan open-ended untuk kemampuan berpikir kreatif matematik peserta didik SMP yang praktis dan valid?

2. Apakah produk pengembangan LKPD berbasis pendekatan open-ended untuk kemampuan berpikir kreatif matematik peserta didik SMP praktis digunakan?

Adapun tujuan dari penelitian ini sebagai berikut:

1. Mengetahui kevalidan LKPD yang berbasis pendekatan open-ended untuk kemampuan berpikir kreatif.

2. Mengetahui praktis atau tidaknya LKPD berbasis pendekatan open-ended untuk kemampuan berpikir kreatif.

\section{METODE PENELITIAN}

\section{Jenis Penelitian}

Jenis penelitian ini termasuk dalam jenis penelitian dan pengembangan atau sering dikenal dengan sebutan Research and Development (R\&D). Metode penelitian dan pengembangan adalah metode penelitian yang digunakan untuk menghasilkan produk tertentu dan menguji kevalidan serta kepraktisan produk tersebut (Sugiyono, 2017). Produk yang dihasilkan bahan ajar berupa LKPD berbasis pendekatan open-ended.

\section{Prosedur}

Prosedur Pengembangan yang diambil sesuai dengan yang di kemukakan Sugiyono (2017: 408-426) langkah-langkah penelitian dan pengembangan ditunjukan diagram berikut. 


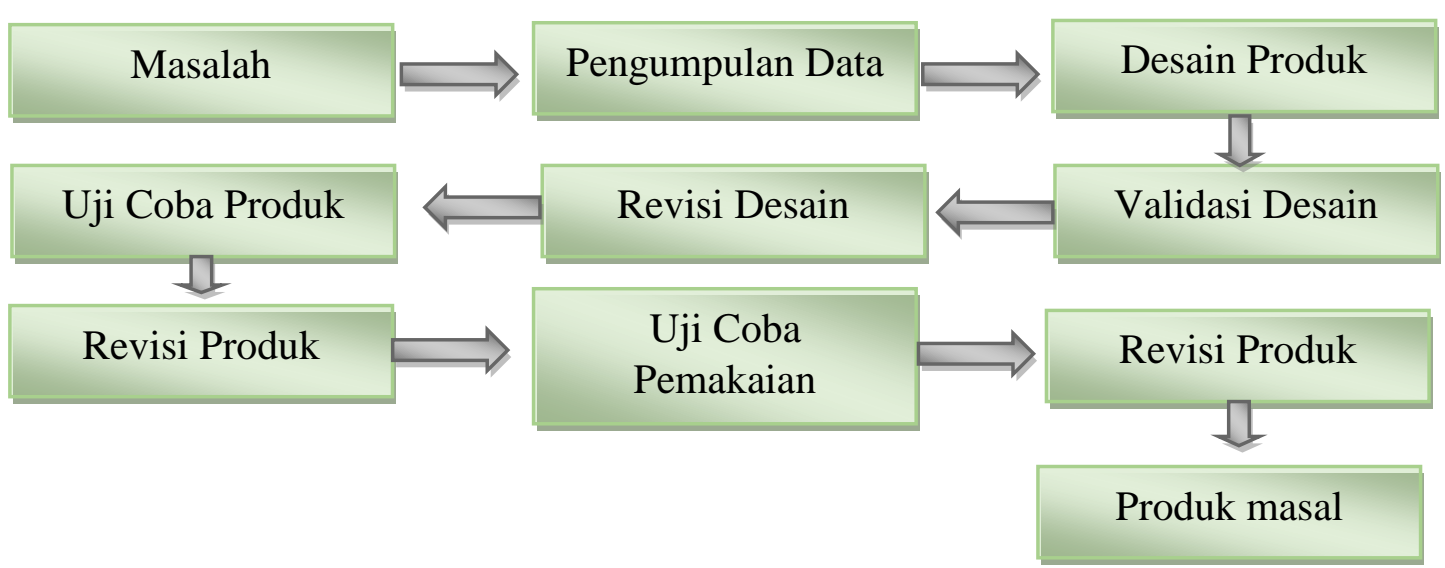

Gambar 1. Diagram langkah-langkah pengembangan dan penelitian.

\section{Teknik Analisis Data}

Validasi produk dilalukan oleh guru matematika SMP. Subjek dalam penelitian ini adalah peserta didik kelas VII SMP Negeri Kasihan dengan jumlah 5 orang peserta didik. sebagai data respon peserta didik terhadap media yang telah dibuat dengan menggunakan angket respon peserta didik. Teknik analisis data yang digunakan dalam penelitian pengembangan ini adalah memodifikasi model ADDIE (Analysis, design, development, implementation, and Evaluation) yang menggunakan tahap-tahap analisis, desain, pengembangan, implementasi dan evaluasi menjadi ADD (Analysis, design, development), hanya sampai pada pengembangan.

Setelah tahap terakhir dari ADD selesai peneliti selanjutnya melakukan analisis data yang di peroleh dari hasil validitas ahli dan angket respon peserta didik terhadap pengguanaan LKPD. Analisis ini dilakukan untuk mendapatkan media LKPD berkualitas baik yang memenuhi sesuai dengan tujuan yaitu memenuhi aspek kevalidan dan kepraktisan. Maka dapat dilihat teknik analisis data yang digunakan sebagai berikut:

1. Analisis kevalidan LKPD

Pada penilaian kevalidan LKPD dilakukan dengan menggunakan lembar validasi yang di isi oleh para ahli dan dianaliasis oleh peneliti sesuai dengan penilaian yang dilakukan para ahli untuk mengetahui tingkat kevalidan dari produk yang dikembangkan.

2. Pada penilaian LKPD berdasarkan kepraktisan dilakuakan dengan menggunakan lembar praktikalisasi dan lembar angket yang diisi oleh siswa. Analisis praktis ini peneliti menggunakan Skala Liket. 


\section{HASIL DAN PEMBAHASAN}

Pengembangan media LKPD berbasis pendekatan open-ended pada materi pecahan dilakukan dengan memodifikasi model ADDIE menjadi ADD yakni menggunakan tahap analisis, tahap perancangan dan tahap pengembangan. Instrument yang digunakan oleh peneliti untuk mengetahui kevalidan dan kepraktisan media yang dikembangkan yaitu menggunakan lembar validasi, lembar praktikalisasi dan lembar angket.

\section{Validasi}

Hasil penilaian dari para ahli terhadap LKPD berbasis pendekatan open-ended untuk kemampuan berpikir kreatif pada penelitian ini dikatakan sangat baik. Validasi terhadap instrumen penelitian dilakukan oleh para validator. Objek penilaian yang dinilai adalah lembar validasi RPP, lembar validasi LKPD berbasis pendekatan Open-Ended, lembar validasi soal berpikir kreatif, Secara umum, hasil penilaian terhadap lembar validasi dan instrumen penelitian adalah layak digunakan dan sangat valid. Adapun hasil validasi LKPD oleh para validator sebagai berikut

Tabel 1. Hasil Validasi LKPD

\begin{tabular}{lccc}
\hline \multicolumn{1}{c}{ Validator } & $\begin{array}{c}\text { Skor yang } \\
\text { Dicapai }\end{array}$ & $\begin{array}{c}\text { Skor } \\
\text { Maksimal }\end{array}$ & $\begin{array}{c}\text { Kriteria } \\
\text { Validasi }\end{array}$ \\
\hline Validator 1 & 80 & 100 & $80 \%$ \\
Validator 2 & 90 & 100 & $90 \%$ \\
Validator 3 & 84 & 100 & $84 \%$ \\
\hline Rata-rata & & & $\mathbf{8 4 , 7 \%}$ \\
\hline
\end{tabular}

Cara perhitungan peneliti dengan menggunakan interval (jarak) dan interpretasi persen disajikan pada tabel 2.

Tabel 2. Interval Penilaian LKPD Berbasis Open-Ended

\begin{tabular}{lll}
\hline No. & Katagori & Interval \\
\hline 1. & Tidak baik & $0 \%-19,99 \%$ \\
2. & Kurang baik & $20 \%-39,99 \%$ \\
3. & Cukup & $40 \%-59,99 \%$ \\
4. & Baik & $60 \%-79,99 \%$ \\
$\mathbf{5 .}$ & Sangat baik & $\mathbf{8 0 \% - 1 0 0 \%}$ \\
\hline
\end{tabular}

\section{Kepraktisan}

Pada penilaian LKPD berdasarkan kepraktisan dilakuakan dengan menggunakan lembar praktikalisasi dan lembar angket yang diisi oleh siswa. Analisis praktis ini peneliti menggunakan Skala Liket. Adapun hasil dari dilakukanya uji praktikalisasi dimodifikasi dengan lembar angket. Dapat dilihat pada tabel 3. 
Tabel 3. Hasil Praktikalisasi LKPD

\begin{tabular}{|c|c|c|c|}
\hline Penilaian & $\begin{array}{c}\text { Skor yang } \\
\text { Dicapai }\end{array}$ & $\begin{array}{c}\text { Skor } \\
\text { Maksimal }\end{array}$ & $\begin{array}{c}\text { Kriteria } \\
\text { praktis }\end{array}$ \\
\hline Siswa 1 & 26 & 48 & $54,2 \%$ \\
\hline Siswa 2 & 40 & 48 & $83,3 \%$ \\
\hline Siswa 3 & 34 & 48 & $70,8 \%$ \\
\hline Siswa 4 & 36 & 48 & $75 \%$ \\
\hline Siswa 5 & 44 & 48 & $91,7 \%$ \\
\hline \multicolumn{2}{|c|}{ Rata-rata } & & $75 \%$ \\
\hline
\end{tabular}

Cara perhitungan peneliti dengan menggunakan interval (jarak) dan interpretasi persen disajikan pada tabel 4.

Tabel 4. Interval Kepraktisan

\begin{tabular}{lll}
\hline No. & Katagori & Interval \\
\hline 1. & Sangat tidak praktis & $0 \%-24,99 \%$ \\
2. & Tidak praktis & $25 \%-49,99 \%$ \\
3. & Praktis & $50 \%-74,99 \%$ \\
4. & Sangat praktis & $\mathbf{7 5 \% - 1 0 0 \%}$ \\
\hline
\end{tabular}

Penilaian yang dilakukan validator terhadap LKPD yang dibuat peneliti, diperoleh hasil yang sangat baik. Hasil validasi ahli yang dilakukan oleh tiga orang validator, secara keseluruhan LKPD memperoleh rata-rata kriteria validasi yang tinggi, yakni sebesar 84,7\%. Dengan rata-rata LKPD sebesar itu, maka terlihat bahwa LKPD berada pada klasifikasi sangat valid. Hal ini menunjukkan bahwa LKPD yang peneliti buat sudah memenuhi kriteria struktur LKPD menurut Depdiknas. Adapun struktur LKPD menurut Depdiknas antara lain memuat judul, petunjuk belajar, kompetensi yang akan dicapai, informasi pendukung, tugastugas dan langkah kerja serta penilaian (Noto \& Hartono, 2018).

Berdasarkan penilaian uji kepraktisan, hasil yang diperoleh menunjukkan bahwa nilai kriteria praktikalitasnya sangat tinggi, dengan mencapai rata-rata sebesar $75 \%$, dengan kata lain tingkat praktikalitas LKPD yang dikembangkan oleh peneliti sangat praktis. Dalam uji kepraktisan pada penelitian ini, peneliti sudah menjelaskan bahwa dimodifikasi dengan lembar angket. Hal ini menunjukkan bahwa LKPD yang dibuat mempermudah siswa dalam meningkatkan kemampuan berpikir siswa pada materi pecahan.

\section{SIMPULAN DAN SARAN}

Berdasarkan hasil dan pembahasan maka peneliti dapat membuat kesimpulan dan saran untuk penelitian ini, sebagai berikut

\footnotetext{
Pengembangan LKS Berbasis Pendekatan Open-Ended untuk Meningkatkan Kemampuan Berpikir 


\section{Simpulan}

Berdasarkan hasil validasi oleh validator terhadap produk yang dihasilkan pada penelitian ini, dapat disimpulkan bahwa produk dari penelitian ini berupa RPP, LKPD. produk ini masuk dalam kategori "sangat valid". Berdasarkan hasil penilaian dari pengguna produk ini, yaitu guru sebagai validator dan peserta didik, secara keseluruhan dapat dikatakan bahwa produk dari penelitian dan pengembangan ini masuk dalam kategori "sangat praktis". Penilaian guru terhadap produk ini, yaitu RPP, LKPD adalah produk yang "sangat praktis".

\section{Saran}

Berdasarkan simpulan yang diperoleh, maka beberapa saran untuk peningkatan kualitas pembelajaran matematika, terutama peningkatan kemampuan berpikir kreatif siswa, adalah: (1) produk ini dapat menyederhanakan struktural kata dalam memahami materi (2) produk ini dapat dimanfaatkan oleh sekolah sebagai salah satu contoh yang dapat digunakan untuk pengembangan bahan ajar lainnya, baik untuk pelajaran matematika maupun pelajaran lainnya, dan (3) produk ini dapat dimanfaatkan oleh guru sebagai alternatif lain pada pembelajaran matematika di kelas dan juga sebagai contoh dalam pengembangan bahan ajar untuk materi lainnya.

\section{DAFTAR PUSTAKA}

Andi, P. (2011). Metode Penelitian Kualitatif dalam Perspektif Rancangan Penelitian.

Yogyakarta: Ar-Ruzz Media.

Anwar, N., Johar, R., \& Juandi, D. (2015). Pengembangan Perangkat Pembelajaran Berbasis

Pendekatan Open- Ended untuk Meningkatkan Kemampuan Berpikir Kreatif Matematis Siswa SMP. Jurnal Didakti Matematika, 2, 52-63.

J.R, E. (1991). Creative Thinking. United State of America: Prentice Hall, Inc.

J Hamdayana. (2014). Model Dan Metode Pembelajaran Kreatif Dan Berkarakter. Jakarta:

Ghalia Indonesia.

Noto, S., \& Hartono, W. (2018). Pengembangan Perangkat Projrct Based Learning ( PjBL ) pada Materi Statistika SMA, 2(1).

Rohati, R. D. F. dan. (2014). Pengembangan Lembar Kerja Siswa (LKS) Berbasis POE (Predict, Observe, Explain) pada Materi Program Linear Kelas XII SMA, 8(1), 97.

S, S. (1997). The significance of an Open-ended Approach. In Shimada, S and Backer, J.P.

Prima, Vol. 3, No. 1, Januari 2019, 35-43. 
the Open-ended Approach. A New Proposal for Teaching Mathematics.

Sabandar, J. (2012). Berpikir Reflektif dalam Pembelajaran Matematika. Prodi Pendidikan Matematika Sekolah Pascasarjana UPI, 1-17. Diambil dari http://file.upi.edu/Direktori/FPMIPA/JUR._PEND._MATEMATIKA/194705241981031

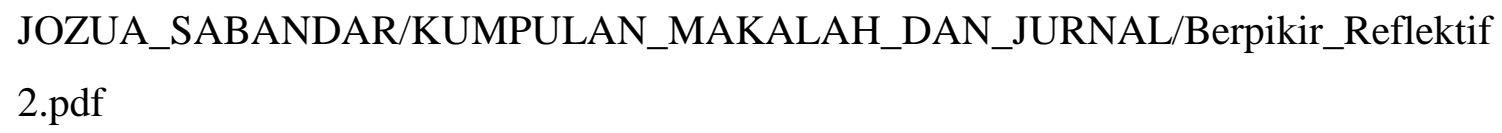

Soeyono, Y. (2014). Pengembangan Bahan Ajar Matematika dengan Pendekatan Open-ended untuk Meningkatkan Kemampuan Berpikir Kritis dan Kreatif Siswa SMA. PYTHAGORAS: Jurnal Pendidikan Matematika, 9(2), 205-218. Diambil dari http://journal.uny.ac.id/index.php/pythagoras/article/view/9081/pdf_1

Sugiyono. (2017). Metode Penelitian Pendidikan Pendekatan Kuantitatif, Kualitatif dan $R \& D$. Bandung: Alfabeta. 